\title{
Western Esotericism in Brazil
}

\author{
The Influence of Esoteric Thought \\ on the Valley of the Dawn
}

Kelly E. Hayes

\begin{abstract}
The Brazilian religion known as the Valley of the Dawn is an international new religious movement known for its eclectic cosmology and collective rituals performed by adepts dressed in ornate garments. Headquartered outside of Brasília, the Valley of the Dawn was founded in the 1960s by Neiva Chaves Zelaya (1925-85) a clairvoyant medium affectionately referred to as Aunt Neiva. This article highlights the work of Mário Sassi (1921-94) and the significance of esoteric thought in the development of the movement's Doctrine. An early convert who became Aunt Neiva's life partner, Sassi was an intellectual seeker who drew selectively on esoteric ideas popularized through theosophical and spiritist texts to interpret and systematize Aunt Neiva's visions. Together Aunt Neiva and Mário Sassi created a Brazilian form of Western esotericism that today includes over 600 affiliated temples across Brazil and worldwide.
\end{abstract}

KEYWORDS: Western esotericism, Theosophy, New Age, Valley of the Dawn, new religious movements, Brazil, Spiritism

Nova Religio: The Journal of Alternative and Emergent Religions, Volume 23, Issue 3, pages 60-85. ISSN 1092-6690 (print), 1541-8480. (electronic). (c) 2020 by The Regents of the University of California. All rights reserved. Please direct all requests for permission to photocopy or reproduce article content through the University of California Press's Reprints and Permissions web page, https://www.ucpress.edu/journals/reprintspermissions. DOI: https://doi.org/10.1525/nr.2020.23.3.60. 


\section{INTRODUCTION}

B razil is fertile ground for the study of Western esotericism, a scholarly field that focuses on a wide array of intellectual currents, practices, and movements in the post-Enlightenment West that center on occult knowledge; that is, ways of knowing rejected by both mainstream religions and the scientific establishment. ${ }^{1}$ Esoteric ideas and practices long have flourished in Brazil, interacting with local realities to produce a rich array of alternative religions, spiritual therapies, healing modalities, philosophies, art movements, and literatures. While this esoteric milieu is evident throughout the country, it is especially visible in Brasília, which has been dubbed the "Mystical City" or "Capital of the New Age"3 due to the especially intense concentration of alternative, esoteric, and New Age communities that have emerged there. The largest and most well-known of these is the Valley of the Dawn (Vale do Amanhecer), a burgeoning new religious movement whose members have constructed their own capital city forty-five kilometers outside of Brasília. The Valley of the Dawn is known for its eclectic cosmology, colorful temple complex, and collective rituals of spirit healing performed by adepts dressed in ornate garments.

Officially called Social Works of the Spiritualist Christian Order (Obras Sociais da Ordem Espiritualista Cristã) or OSOEC, the Valley of the Dawn was founded by Neiva Chaves Zelaya (1925-85), known to her followers as Aunt Neiva, a widowed former truck driver and clairvoyant medium who emigrated to the federal district in the late $1950 \mathrm{~s}$ to work in the new capital city then being built. ${ }^{4}$ With the help of Mário Sassi (1921-94), an early convert who left his family, career, and former life to become her companion and the official interpreter of her spiritual visions, Aunt Neiva established an elaborate religious system that assimilated various ideas present in Brazil during the 1960s and '70s, reconfiguring them within a doctrinal framework grounded in theosophical metaphysics, (Kardecist) spiritist practice, and an esoteric version of Christianity emphasizing Jesus' ethical teachings as a means of karmic redemption. Since Aunt Neiva's death in 1985, the Order, as it sometimes is called, has become an international religious movement with affiliated temples throughout Brazil as well as in Europe and North America.

As Aunt Neiva's romantic partner and confidant, Sassi was privy to intimate details of her personal life as well as the ongoing psychic phenomena that she experienced until her death. By systematizing the content of Neiva's visionary experiences and developing an interpretative framework for them based on esoteric metaphysics, Sassi developed the intellectual foundation of the movement's theology. ${ }^{5}$ In this article, I discuss Sassi's alliance with Aunt Neiva and his doctrinal contributions to the Valley of the Dawn, drawing on my own fieldwork at the movement's 


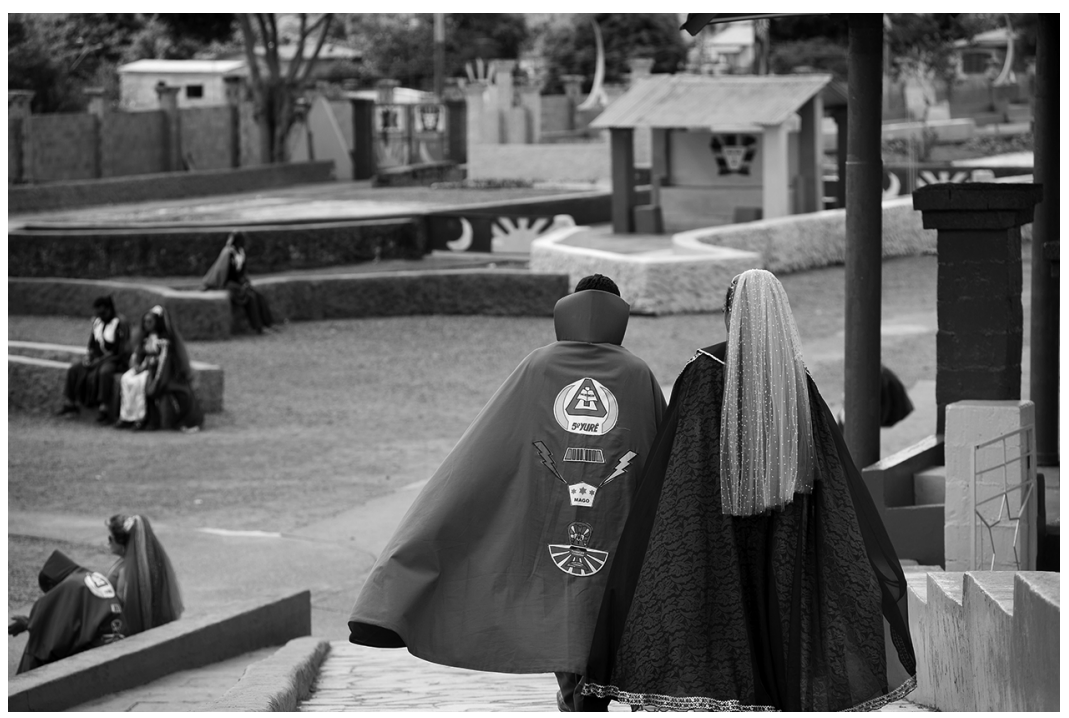

Image 1. Valley of the Dawn (credit: Márcia Alves)

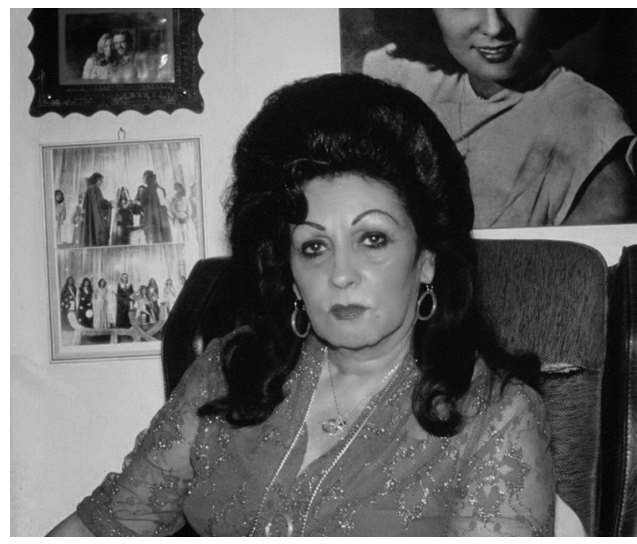

Image 2. Aunt Neiva (credit: Arquivo do Vale do Amanhecer)

Mother Temple as well as interviews with two of Sassi's surviving children. ${ }^{6}$ While it is clear that Sassi read widely in the esoteric literature available in Brazil at the time, I focus principally on his use of concepts associated with Theosophy and spiritist texts to position Aunt Neiva's movement as advancing humanity's spiritual evolution by delivering a means for karmic redemption. In the final section, I make the case that the collaboration between the charismatic medium and the homegrown intellectual embodies a form of Western esotericism that is both transnational and Brazilian. 
Nicknamed "the intellectual" soon after he joined the community, Sassi worked closely with Aunt Neiva, editing her writings and biographical materials, clarifying the Order's beliefs in official publications, helping coordinate and lead its corpus of rituals, and instructing initiates. The lectures and training materials he produced were written down or recorded and continue to circulate among members today. All of this work, Sassi told a researcher in the mid-1970s, was "a collaboration with Aunt Neiva who, inspired by the entities of the Astral Superior (superior astral world), transmitted the messages" that Sassi interpreted and divulged. ${ }^{7}$

A voluble personality, Sassi served as the movement's secretary general and official spokesperson, giving interviews to the press and receiving journalists, researchers, religious authorities, and other visiting dignitaries-responsibilities that increased as Aunt Neiva's health declined and she became tethered to an oxygen tank toward the end of her life. Sassi's explanations of the Doctrine, as Valley members like to call it, thereby shaped how others with whom he came into contact understood and reported on the Valley of the Dawn. And by facilitating the Doctrine's reproduction in affiliated temples that could function without Aunt Neiva's presence, Sassi's contributions were crucial to the movement's growth. Today his oeuvre and the cartas or letters penned by Aunt Neiva to her followers constitute the two most important sources of scriptural authority. Nonetheless, while scholars and Valley members alike have written numerous monographs and biographies about Aunt Neiva, comparatively little has been written about Mário Sassi even though his importance to the movement is recognized universally. ${ }^{8}$

In examining Mário Sassi's contributions, I highlight the significant influence of key concepts associated with Theosophy on the movement's Doctrine, which has not been adequately recognized. ${ }^{9}$ Because of the Valley of the Dawn's emphasis on spirit mediumship and rituals of disobsessive healing (cura desobsessiva) ${ }^{10}$ scholars have characterized the Valley of the Dawn as either an "offshoot"11 or an especially syncretic form of Kardecist spiritism: a "veritable sponge that absorbs and unites a host of belief systems into an original doctrine," as one researcher put it. ${ }^{12}$ While there is no doubt that Kardecist spiritism was an important part of the mix, I argue that theosophical philosophy provided a conceptual apparatus capable of assimilating and integrating the diverse sources on which Mário Sassi and Aunt Neiva drew.

In other words, the theosophically oriented theology that Mário Sassi constructed served as a master key through which he and Aunt Neiva organized, reinterpreted, and resignified other influences and integrated them into a unitary conceptual system, or as Sassi characterized it, a "doctrine of universal meaning based on the Christic system." 13 Among other things, this enabled traditional spiritual beings from the world of popular Brazilian religions, such as Aunt Neiva's chief spirit 
mentor Father White Arrow (Pai Seta Branca), to be construed as local avatars of highly evolved planetary masters working for the spiritual progress of humanity and the advancement of the planet.

\section{MÁRIO SASSI: INTELLECTUAL ARCHITECT OF THE VALLEY OF THE DAWN}

By his own account, Sassi first encountered Aunt Neiva in 1965 when he gave an unnamed person a ride to her house. ${ }^{14}$ Already a medium of some renown, Aunt Neiva had established a small spiritual community in Taguatinga, one of several working-class satellite cities outlying Brasília, when Sassi arrived at her doorstep. Despite his initial skepticism, Sassi reported that his reservations faded when Aunt Neiva recounted intimate details of his life that he had not previously disclosed to anyone. After a conversation with her that lasted into the morning hours, he left feeling, he later wrote, "as if my whole being had been invaded by unknown forces as a new world opened up to me."15 The sensation of enchantment that pervaded his initial encounter with Aunt Neiva was so strong that, at the very end of his life, Sassi remembered the conversation as being "so seductive, so charming, that I wanted to continue... I stayed until dawn, had dinner with her in the kitchen of the temple... and only returned to my house at daybreak." ${ }^{16} \mathrm{He}$ began to visit Aunt Neiva regularly, commuting to Taguatinga from his family's home in the capital to learn more about Neiva's mission and the work of the small group that had gathered around her.

In 1968, three years after his first encounter with Aunt Neiva, Sassi joined the Order full-time, leaving behind his job, wife, and family. He was convinced, he later wrote, that Aunt Neiva was a "superbeing" who "represent[ed] the Spirit of Truth and whose fundamental mission [was] to prepare us for the future." His own mission would be to "bear witness to the Spirit of the Truth" by synthesizing Aunt Neiva's visionary experiences and forging a comprehensive doctrinal system from the revelations that she claimed to receive from highly evolved entities inhabiting other dimensions. ${ }^{17}$ As time went on, Sassi began to take on a leadership position within the community, "not so much for my qualities," he admitted, "but for my availability. I had been able, at a great price, to detach myself from common obligations, and so gradually I became adapted to my mission. As I experienced more, I understood better the depth of Neiva's mission." ${ }^{18}$ In 1969, the group relocated to an area six kilometers outside of the town of Planaltina. Its new residents called it Vale do Amanhecer, or Valley of the Dawn.

A period of great ritual and theological efflorescence followed and over the next decade the community grew exponentially from several dozen to tens of thousands of mediums. ${ }^{19}$ In pedagogical lectures and 


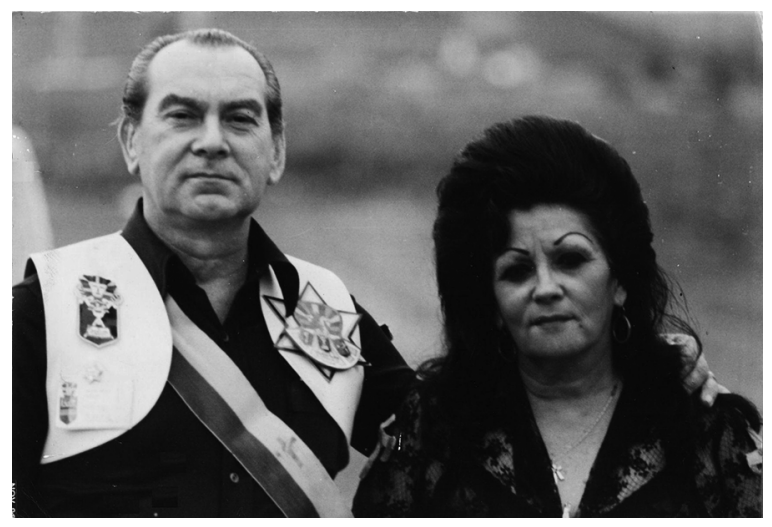

Image 3. Mário Sassi and Aunt Neiva (credit: Arquivo do Vale do Amanhecer)

books published by the Order, Sassi endeavored to build a coherent metaphysical foundation for an emerging religion whose beliefs and practices were still being revealed, drawing heavily on his knowledge of esoteric literature for the task. ${ }^{20}$ His output is steeped in a language common to this literature, with references to vibrational fields, magnetic fluids, ectoplasm, chakras, subtle energies, and so forth, as well as complex, pseudo-scientific explanations of nonempirically verifiable phenomena such as the laws governing the different terrestrial and astral dimensions or what they call the "scientific" basis for communication with superhuman entities. ${ }^{21}$

Although Sassi's personal library has not survived, he had access to a diverse body of esoteric and New Age literature from around the globe as well as the popular works of Brazilian spiritist writers such as Francisco (Chico) Xavier (1910-2002), Bezerra de Menezes (1831-1900), and Edgard Armond (1894-1982). Theosophical literature had circulated in Brazil since the first decades of the twentieth century when members of a spiritist community called Love of God (Amor a Deus) established the first Brazilian lodge affiliated with the Theosophical Society. ${ }^{22}$ Shortly thereafter, works by Charles W. Leadbeater (1854-1934) and other prominent theosophists were translated into Portuguese and disseminated in Brazil. ${ }^{23}$ Spiritist newspapers, conferences, radio programs, and other media also were an important vector through which theosophical ideas spread in Brazil throughout the twentieth century. While Sassi never explicitly mentioned Theosophy or cited the works of any theosophists, there were multiple ways that he, as well as Aunt Neiva, would have encountered basic theosophical themes.

Sassi particularly enjoyed science fiction and espionage novels, he told researcher Ana Lúcia Galinkin in the mid-1970s, favoring the works of English-language authors, which he read in the original language. ${ }^{24}$ 


\section{Nova Religio}

Sassi's daughter Cací also recalled her father reading books in English, which he had learned as a student. Both Cací and her brother Iraê remembered their father's lifelong fascination with unconventional forms of spirituality and described him as a voracious reader of esoteric literature of various kinds. "He was fascinated with those science fiction collections and things like that-esoteric subjects," Cací recalled. "He always had an unorthodox side.... He always was reading books about Buddhism, about spirituality, he had this curiosity." ${ }^{25}$ As a result of their father's interest, Iraê observed that his children "were readers of esoteric books and things of that nature. We children were quite enthused with the ideas that he had about extraterrestrials." 26

Sassi's influence began to wane following Aunt Neiva's death in 1985. After a series of disagreements about the future direction of the community, Sassi left the Valley of the Dawn for a nearby town where he founded his own spiritual community, the Universal Order of the Great Initiates (sometimes called the Temple of the Sun by Valley members), with his third wife Lêda Franco de Oliveira, whom he had married in 1986. ${ }^{27}$ He died in December of 1994 after several years of declining health following a stroke in 1991. ${ }^{28}$ Despite the acrimonious disputes that led to his departure, Mário Sassi is held in great esteem by contemporary Valley of the Dawn members who remember him as a great intellectual and "spiritual scientist" charged with interpreting Aunt Neiva's visions. ${ }^{29}$

In the next section I offer a brief overview of the Order's metaphysics before examining how Sassi's account of the community's proto origins draw specifically on two esoteric streams: (1) the theosophical doctrine of root races; and, (2) a narrative, advanced in two popular spiritist works by Brazilian authors, that depicts human evolution as the work of a group of highly advanced extraterrestrials exiled from a distant star. Although the Valley of the Dawn as a whole incorporates ideas and practices from multiple religious and pop culture sources, my discussion concentrates on how Sassi deployed these particular conceptual resources to synthesize the knowledge he believed Aunt Neiva received with an esoteric metaphysical and macrohistorical framework that is universal in scope. ${ }^{30}$

\section{THE METAPHYSICS OF THE VALLEY OF THE DAWN}

The influence of esoteric and, more specifically, theosophical ideas on the Valley of the Dawn's worldview is evident in its vision of the septenary nature of the cosmos and human beings; their cyclical progression through distinct, evolutionary stages; the idea that human beings have been guided along their evolutionary path by spiritually advanced Masters; an emphasis on initiatic wisdom traced back to the 
"Great Orient" of India, Egypt, and other ancient civilizations as well as the mythological continents of Lemuria and Atlantis; and the central role of karma and reincarnation as forces driving human evolution.

Ontologically, the Order distinguishes two aspects of the self: the individuality or higher, spiritual self that experiences different incarnations over time and the personality, the contingent or material self that is limited to the present life. Although I do not address it here, other concepts developed by Helena P. Blavatsky and further explained by second-generation Theosophists such as Charles W. Leadbeater and Alice Bailey (1880-1949) also appear in the Valley of the Dawn's teachings in modified form. This includes the occult hierarchy of the Seven Rays, evolved spiritual beings called Devas, the seven Ministers or planetary spirits, and the fifth initiatory cycle, along with references to chakras, prana, Rama and other Indian concepts disseminated to the West mainly through theosophical literature.

In accordance with theosophical cosmology, the Valley of the Dawn contends that there are seven planes of existence governing both macrocosm and microcosm, including the spiritual, ethereal (or psychic), and material dimensions, each of which is composed of its own distinct combination of matter and spirit. Driven by universal laws such as karma and reincarnation, the entire cosmos (including the Earth and humanity) follows a grand scheme of evolutionary development that unfolds in sequential cycles as spirit gradually descends into matter and then, reversing course, ascends back to its rarified source-a trajectory that Garry Trompf characterized as a "cosmic U-curve." ${ }_{11}$ The Valley of the Dawn teaches that the transition between cycles is especially fraught and marked by social conflicts, environmental catastrophes, and increased human suffering. While we are living in the third millennium of the common era according to the Western calendar, the Doctrine holds that actually we are still in the midst of the transition to the Third Millennium when the tónica or prevailing matter-spirit "tone," as Sassi described it, will shift as the Earth passes into a different state.

While physicality is a temporary state associated particularly with terrestrial existence, the spirit itself is transcendental, existing both before and after the physical body and, following the laws of karma, periodically reincarnating on Earth in order to atone for past acts and learn lessons that will facilitate continued evolution. Like many other Brazilian groups influenced by Kardecist spiritism and esoteric philosophies, the Valley of the Dawn understands the Earth to be a place of expiation where one can either make amends for one's karmic debts, evolving into a higher state, or accrue new karmic debts thus extending the cycle of reincarnation into the future. Reincarnation on Earth is a precious opportunity to work toward one's own spiritual evolution as well as that of the entire planet Once individuals have evolved to the point that incarnation on Earth is no longer necessary, they continue 


\section{Nova Religio}

their evolutionary journey through other dimensions until returning eventually to the divine source, which the Valley of the Dawn understands as the Christian God. According to the Doctrine, certain highly evolved beings within the cosmic hierarchy, continue to guide human beings on the terrestrial plane as mentors and "spirits of light."

Valley of the Dawn members understand themselves to be part of a unique "tribe," known as Jaguars (Jaguares), whose spiritual ancestors derive from a race of extraterrestrials originally sent to Earth with a mission from God to advance humanity's cultural and spiritual evolution. Led by a spirit of light known as Father White Arrow, these spirits are said to have passed through multiple lifetimes over the millennia, incarnating as Spartan warriors, Egyptian royals, Roman legionnaires, Russian gypsies, and colonial Brazilians, among many others. The total of past lives constitutes the Jaguars' transcendental heritage, a karmic ledger of collective deeds, misdeeds, and their karmic consequences. Father White Arrow, having completed his own evolutionary journey on Earth, commissioned Aunt Neiva to carry on his mission of helping humans through the difficult transition between millennial cycles. Members consider themselves to be present-day Jaguars, reunited by Aunt Neiva on the cusp of the New Age in accordance with Father White Arrow's plan.

In a nod to Theosophy's concept of the Masters of the Wisdom, Jaguars who have completed the requisite initiations are referred to collectively as the mestrado or corpo mestrado (literally the master's degree or the corps of the master's degree); individual men are called masters (mestres) and women are called nymphs (ninfas). Like Blavatsky, Alice Bailey, and other significant figures involved with the Theosophical Society and its offshoots, Aunt Neiva was tutored by her own living Master of Wisdom, a Tibetan monk named Umahã, from whom she claimed to receive esoteric knowledge fundamental to the establishment of the Order. ${ }^{32}$ Despite living in a monastery in the mountains of Tibet, Umahã is said to have met daily with Aunt Neiva on the astral plane in order to teach her ancient wisdom and esoteric (or "initiatic" in the movement's argot) techniques of "high magic" (alta magia). At the end of this five-year apprenticeship, Aunt Neiva received the

consecration that would enable her to definitively implant, some time later, the structure necessary to realize the technical-ritual system conceived by her spiritual mentors.... On the spiritual plane, she began to be known as Koatay 108, Koatay meaning originality, original or singular, and the 108 mantras that empower the complete mestrado. ${ }^{33}$

Alice Bailey's Master Djwal Khul, known as “The Tibetan” or D.K., also was described as an abbot of a Tibetan monastery. Although Valley of the Dawn Doctrine does not explicitly connect Aunt Neiva's Tibetan Master to Djwal Khul or other theosophical Masters, in his preface to 
Neiva's autobiography, Sassi wrote that Kuthumi (or Koot Hoomi, as it is more often spelled), one of the two Masters of Wisdom whom Blavatsky credited as the true founders of the Theosophical Society, was one of the guises by which Father White Arrow was known during his sojourns on Earth. ${ }^{34}$

\section{MACROHISTORY: THE JOURNEY OF THE JAGUARS}

In his 1974 book 2000: The Conjunction of Two Planes, Sassi outlines a macrohistory of both humanity and the Jaguars as revealed to Aunt Neiva, who appears as a character in the book, by highly evolved beings from a distant star. Sassi's sweeping account, the subject of this section, presents the proto-origins of the Jaguars in terms of Blavatsky's theory of root races (although Sassi never used that designation). As I discuss in more detail in the next section, the narrative's basic storyline adapts a storyline found in two influential spiritist books by the Brazilian writers Chico Xavier and Edgard Armond. ${ }^{35}$

Typically Aunt Neiva's visionary experiences involved spirit entities familiar within the popular Brazilian religions of Umbanda, spiritism, and folk Catholicism. Father White Arrow, for example, represents a well-known type of spirit entity recognized in Umbanda and other Afro-Brazilian traditions as a caboclo, or the spirit of an undomesticated Indian. Other important spirit mentors in Aunt Neiva's development as a medium were several pretos velhos, spirits of elderly black slaves beloved in Umbanda for their wisdom, humility, and grandparently mien. However in 1959, Sassi reports, she began to have contact with entities of a very different kind: inhabitants of the planet Capella (Capela). ${ }^{36}$ This distant star, according to Sassi, "has presided over the destiny of the Earth from the beginning." 37 Unlike Neiva's other spirit guides, the Capelinos or Capellans are physical, material beings: they are "molecular," Sassi explains, but with a different "composition" than humans. Concerned with the fragile state of human progress, they have initiated contact with Aunt Neiva in order to help humanity through the difficult transition to the Third Millennium. ${ }^{38}$

Like attentive doctors or teachers, Sassi writes, the Capelinos have accompanied human beings throughout the centuries, "suffering with us, inventing new teaching methods, refining their contacts and continually searching for ways of guiding us." 39 They cannot tolerate the density of the Earth's atmosphere, however, so they mostly communicate by projection, "in a way similar to the transmission of television images." 40 According to Sassi, they occasionally come in special vehicles, giving rise to the numerous tales of flying saucers that have become popular lore around the world. In another book, Sassi offers a more fanciful take, describing the Capelinos as having "all the charm of the traditional 


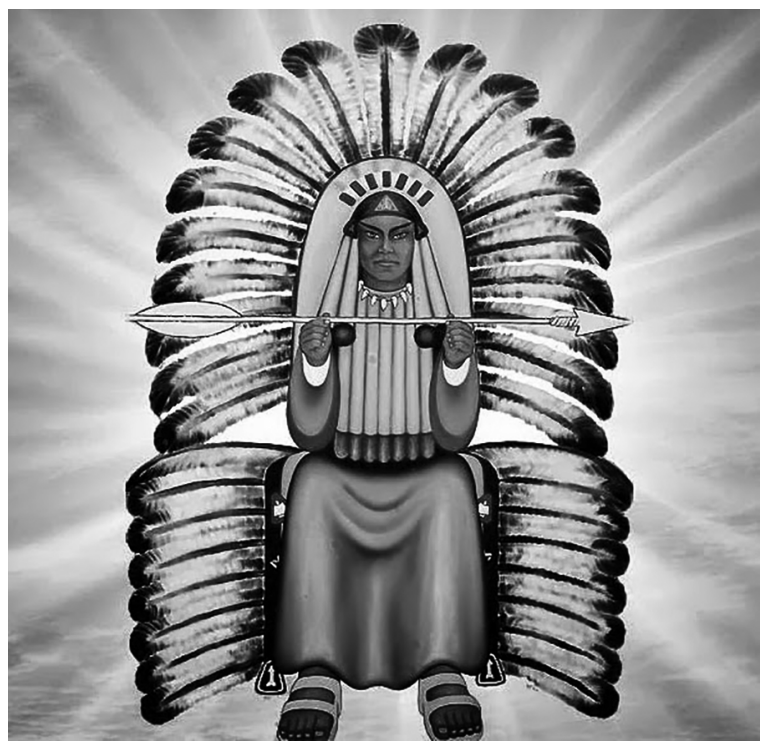

Image 4. Father White Arrow (credit: Arquivo do Vale do Amanhecer)

blond and beautiful figures, belts full of mysterious buttons, typical of science fiction literature." 41

Journeying on such a spacecraft piloted by her Capelino hosts, Aunt Neiva learns that the Earth was first colonized 32,000 years ago by a vanguard from the "mother-planet" Capella. ${ }^{42}$ Sent to make Earth more suitable for civilization and accelerate humanity's cultural and spiritual evolution, these alien missionaries established themselves in seven centers spread over the globe. Sassi refers to them as Equitumans, a term that appears to be unique to the Valley, and describes them as a race of giant beings more spiritual than physical in nature. In their stature and asexual means of reproduction, the Equitumans very much resemble the Lemurians, the third root race in Blavatsky's septenary schema. ${ }^{43}$

Like the Lemurians, the Equitumans became increasingly entrapped in the material and physical world with the passage of time. As they succumbed to corporality and the desire for power, the Equitumans "began to distance themselves from their Masters and the original plans," Sassi wrote. ${ }^{44}$ Finally they were eliminated from the Earth when Father White Arrow was dispatched to crash his spacecraft into the main Equituman settlement. According to Sassi, the crater left by the impact formed Lake Titicaca, the mythical birthplace of the Incan civilization. ${ }^{45}$ For this reason, many Valley of the Dawn members today believe that the ancient Incans were actually Equitumans. In homage to the Jaguars' mythological connection to the Andes, the Valley's mother temple complex contains an artificial lake known as "the teardrop of Lake Titicaca," 


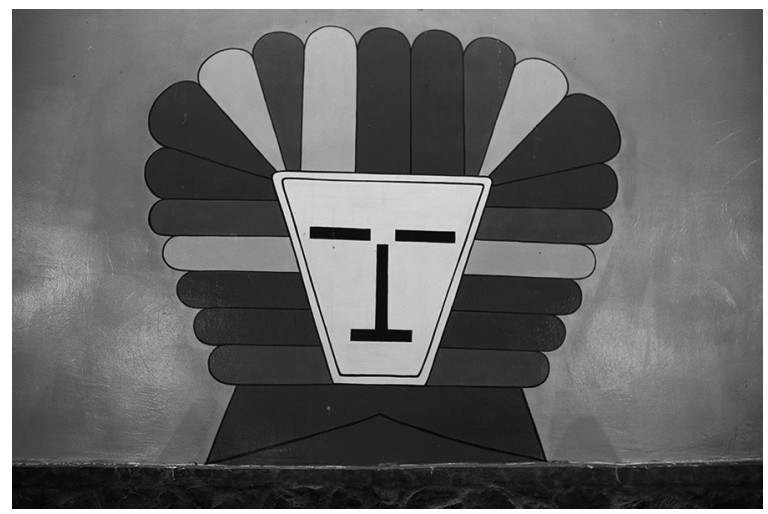

Image 5. Jaguar Symbol (credit: Márcia Alves)

which Aunt Neiva inaugurated in 1978. Also referencing this connection, the symbol representing the Jaguars, found throughout the Valley of the Dawn, is modeled on the iconography of Viracocha, the creator god of the Incas and their predecessors.

The "most pure" remnants of the Equitumans were saved, according to Sassi, and charged with restarting the civilizing process. ${ }^{46}$ Much like the Atlanteans, Blavatsky's fourth root race, known as the Tumuchy, possessed highly advanced scientific and technological capacities. They displayed great skill in "manipulating planetary energies," Sassi wrote, for which purpose they built pyramids and other ancient structures for calculating the relations between various celestial bodies and maintaining communications with Capella. Spread out among seven centers around the world, including sites in ancient Egypt, the Himalayas, the Andes, and the mythological continent of Atlantis, the Tumuchy's headquarters and "center of interplanetary communication" was Easter Island, known to Valley of the Dawn adherents as Omeyocan. ${ }^{47}$ According to the Order, these seven centers formed seven rays (raios) or roots (raizes), a kind of repository for cosmic energies invoked by present-day members in numerous rituals. Although humans don't recall the Equitumans and Tumuchy today, Sassi notes, the memory of them was transformed over time into the various myths of gods who brought civilization to humans, a claim that Blavatsky also made about their corresponding root races. Aunt Neiva considered Sassi a representative of the Tumuchy legacy and gave him the title of Master Tumuchy.

Succeeding the Tumuchy were the Jaguars. Like their fifth root race counterparts, the Jaguars emerged from a core group of Tumuchy and are said to have established the advanced civilizations of the Mayas, Egyptians, Incans, Romans, and so forth. Sassi describes them as "great manipulators of social forces" who left their mark on various ancient 


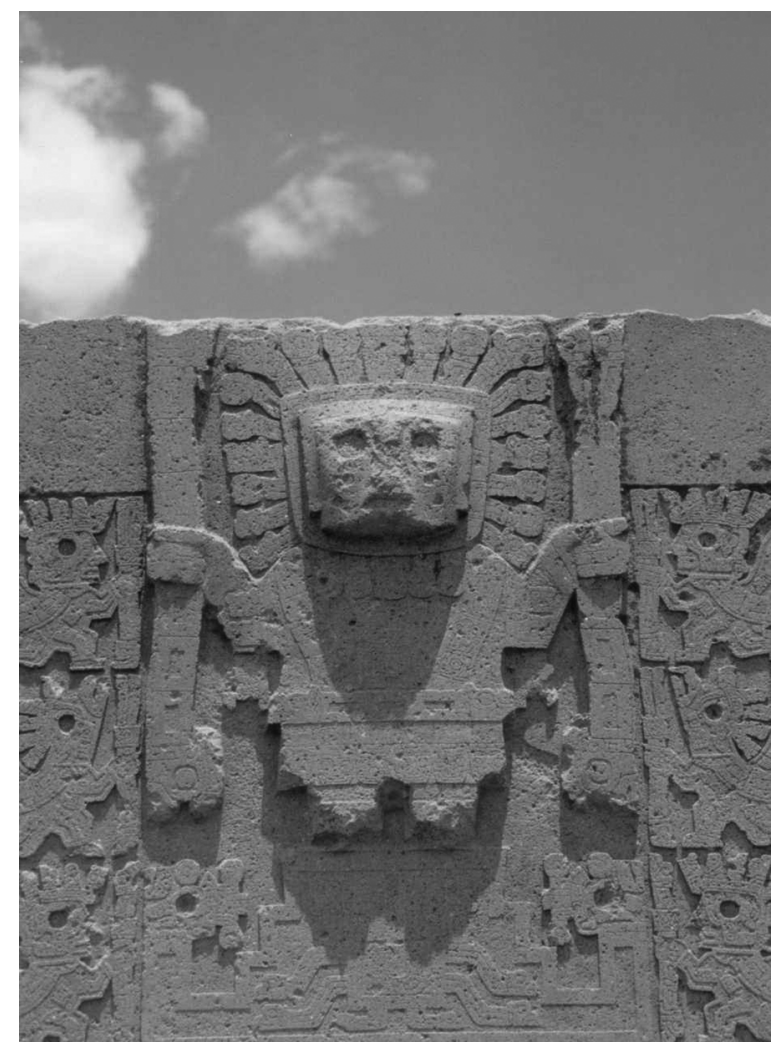

Image 6. Viracocha, Incan God (credit: Wikimedia, Creative Commons License)

peoples. However, following the trajectory of decline established by their predecessors, the Jaguars' descendants veered away once again from their civilizing mission as their earthly incarnations were seduced by material power. The result was an era of particular barbarity, warfare, and destruction. Finally, Sassi declared, "the Master of Masters decided to come to Earth personally" and Jesus was born. ${ }^{48}$ This marked the advent of the "Christic System," a mechanism for karmic redemption based on Christ's moral teachings of unconditional love, humility, forgiveness, and the practice of charity. ${ }^{49}$ And thus "Spirit once again began to reassert its presence," Sassi wrote, albeit in "continuous struggle," with the more primitive forces of the material world. ${ }^{50}$

According to Sassi, those incarnated spirits who adopted the Christic System or School of the Way as a means to return to their original mission became known as Jaguars. This name honors the group's collective incarnation as a group of indigenous Indians living in the mountainous Andes during the period of Spanish colonization led by none other than Father White Arrow in his final incarnation on Earth. Since 
that era, the Jaguars have been working off their karmic debts in different incarnations across time and space, from colonial Brazil to the steppes of nineteenth-century Russia, before being reunited at the Valley of the Dawn by Aunt Neiva. By exemplifying Jesus's teachings of love, humility, and forgiveness, Valley of the Dawn members believe they can redeem the negative karma of their transcendental heritage before the final transition to the Third Millennium, when the era of karmic redemption will close as the Earth enters a new stage.

\section{THE EXILES OF CAPELLA}

The claim that highly evolved beings exiled from Capella were responsible for catalyzing humanity's spiritual and cultural evolution was advanced in Chico Xavier's psychographed ${ }^{51}$ work A Caminho da Luz: História da Civilização à Luz do Espiritismo, published in 1939. Edgard Armond later took up the same theme in his own 1949 book Os Exilados de Capela, which draws on Xavier's narrative as well as Allan Kardec's Genesis, first published in 1868. ${ }^{52}$ Both Xavier and Armond trace out a panorama of cosmic and human history that synthesized Kardecist spiritism with theosophical concepts, especially as articulated by second-generation spokespeople such as Charles W. Leadbeater, Annie Besant, and Alice Bailey who, to a much greater degree than Blavatsky, preserved a salvific or even divine role for Jesus Christ while reinterpreting him as a celestial Master. Both authors attempted to harmonize the theosophical vision of humanity's journey through different evolutionary stages or root races with the biblical account of creation, relying on Kardec's notion of the "Adamic race" to do so. ${ }^{53}$ Sassi certainly was familiar with these pivotal touchstones of spiritist literature in Brazil, which circulated widely in the 1950s and 1960s and continue to be popular references today.

Central to the Capellan thesis is the idea that the exiles are superior to human beings both intellectually and spiritually and that their arrival on Earth enables humanity to progress from a more primitive to a more advanced state and to establish technologically sophisticated civilizations in Egypt, India, and the mythical Atlantis, among other locales. Xavier and Armond both identified the Capelinos as being the same colony of spirits "from another sphere" to which Allan Kardec referred to in Genesis as the origin of the Adamic race: "the race which has pushed all other races forward." 54

Like his forbears Xavier and Armond, Sassi refers to these ancient extraterrestrials as Masters and presents them as highly developed culturally, technologically and morally. While not perfect, they are protoChristians who are guided by "the principle of the Law of Forgiveness, the Christic Law." 55 They are, Sassi observes, "our last hope for the 


\section{Nova Religio}

salvation of our heritage and the preparation of those of us who will continue our race." ${ }^{56}$ Much of their work "is to protect men from their own misdeeds, lest they be destroyed before time, before it has awakened its Christic spark, its inner light." 57

The notion of Christ as a kind of eternal principle that pre-exists and is distinct from (although embodied by) Jesus found a ready audience in Brazil. Like most Brazilian spiritists, Xavier and Armond regarded Jesus as a highly evolved spirit whose major contribution to humanity was his wisdom and moral teachings rather than his suffering and death. Jesus figures prominently in Armond's account of the Earth's and humanity's origins, for example, where he is described as the "sublime architect and divine planetary director" of the universe. ${ }^{58}$ Likewise, Sassi's Jesus was an interstellar chief executive who established a cosmic system of atonement. Sassi provided this explanation:

With Jesus came the most perfect organization: giant spaceships with pilots experienced with the etheric dimensions swept the dense matter and opened pathways to Heaven. Spatial platforms were established in order to receive the spirits who were beginning to free themselves from the physical yoke and the ethereal prison. ${ }^{59}$

According to the Doctrine, this otherworldly system of spatial platforms or transit houses (casas transitórias) is a vast processing center where recently disincarnated spirits go to prepare for the next phase in their evolutionary journeys. Beyond my scope, but worth noting, is that this system of spatial platforms includes the Canal Vermelho, or Red Canal, which is described in identical terms in another of Chico Xavier's psychographed works, Nosso Lar (literally Our Home, translated into English as The Astral City).

Although some Capelinos always have lived on Earth among us, Sassi wrote, others inhabit the astral realms, serving as spiritual mentors for Valley members or assisting recently disincarnated spirits in the Red Canal. ${ }^{60}$ They communicate with humans through mediumship, projecting themselves either from Capella or their spaceships in the astral world (which normally are invisible from the terrestrial world). In the near future, Sassi announces, "they will come as physical beings, astronauts, spatial beings adjusted to new relational norms, new methods of helping their brothers on Earth." ${ }^{1}$ Fearing that the suffering generated by the transition to the Third Millennium would compromise the fragile progress that they had achieved on Earth, they recruited Aunt Neiva to help in their mission.

In Conjunction Sassi narrates Aunt Neiva's encounters with several Capelinos who bear names that, to a Brazilian ear, have a distinctly foreign ring: Stuart, Johnson Plata, and Edris. These names further underline the Capelinos' status as beings markedly different from 


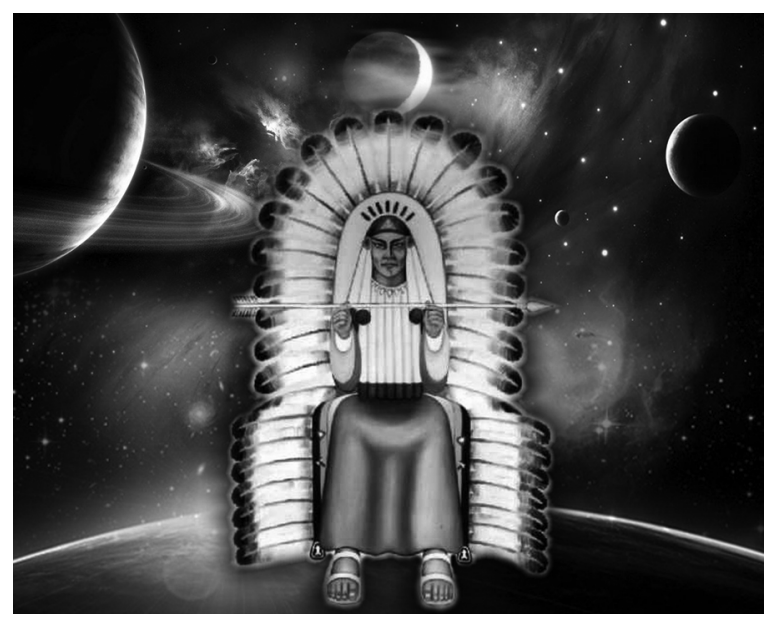

Image 7. Father White Arrow, Cosmic Master (credit: Arquivo do Vale do Amanhecer)

Aunt Neiva's traditional spirit guides. Taking Neiva for interstellar rides in their spaceships, they show her Capella and explain the various challenges they have faced trying to facilitate human evolution over the last many millennia, recounting the stories of the Equitumans and the Tumuchy outlined previously. In these dialogues, we can discern Sassi's efforts to integrate certain details of Aunt Neiva's visions into a broader exegetical framework informed by his reading of esoteric literature-a project that interweaves narrative reconstructions of incidents in Aunt Neiva's spiritual biography with Sassi's macrohistorical, metaphysical, and theological explanations.

Sometimes this involved reinterpreting locally significant superhuman figures, such as the caboclo (Indian) spirit Father White Arrow, as Brazilian avatars of cosmic Masters dedicated to fostering human spiritual evolution. ${ }^{62}$ Father White Arrow played a key role in the saga of the Jaguars as a divine emissary; according to the Doctrine, he arranged for Aunt Neiva to be initiated into alta magia (high magic) by the living Tibetan Master of Wisdom Umahã. Similarly, Tiãozinho, one of Neiva's oldest and most steadfast spirit guides, eventually revealed himself to be the Capelino Stuart. After Tiãozinho's earthly death, Sassi explained, he continued his evolution in the astral world as Stuart, studying and eventually graduating as a "sidereal engineer, a specialist in the spiritual world dealing with planetary problems." ${ }^{63}$ On the terrestrial plane he continued to accompany Aunt Neiva in the guise of Tiãozinho, advising, instructing, and helping resolve problems as he always had.

Even Jesus, the most Christian figure in the Valley of the Dawn's pantheon, was transformed into a cosmic magus and astral engineer. While acknowledging the image of Jesus presented in the Gospels and 
Catholic tradition, the Order teaches that between the ages of twelve and thirty, Jesus resided in the Himalayas where he was initiated into alta magia by seven monks, among them the Dalai Lama. ${ }^{64}$ This "initiatic" training enabled Jesus to create the astral system of transit houses where disincarnated spirits are helped along in their evolutionary progression. Known to Valley members as the Caminheiro, or Wayfarer, Jesus is

the one who is always present with us, pointing us to the New Road, helping us and protecting us in our apprenticeship in the School of the Way, permitting our work helping our disembodied brothers who are being assisted in the Transit Houses that he established. ${ }^{65}$

Some observers have linked the Valley of the Dawn's Jesus, with his white robes and sandals, to the "hippy Jesus" prominent in pop culture products of the 1970 s such as Jesus Christ Superstar. ${ }^{66}$ But an alternate translation of Caminheiro is Pilgrim, which suggests a theosophical connection more in line with the Valley of the Dawn's conception of Jesus as a cosmic Master trained in Tibet and sent to Earth to course-correct the divine plan for human evolution. In Blavatsky's thought, as described by Robert Ellwood and Catherine Wessinger, Pilgrims are highly evolved "individual centers of consciousness" who have completed a full course of evolution, progressing from the Source through each of the seven worlds and back. Masters were those Pilgrims "well in advance of the norm in collective evolution" who were ranked in an Occult Hierarchy and "directed the divine plan of collective evolution back to the Source"-an apt description of Jesus the Caminheiro. ${ }^{67}$ Although Aunt Neiva did not claim to communicate directly with Jesus, as did her other mentors, she always positioned the Order as exemplifying Jesus's teachings and referred to herself as the Jaguars' Mother in Christ.

\section{CONGLUSION}

As Aunt Neiva's partner, trusted confidant, and privileged interlocutor, Sassi had a profound influence on the doctrinal and material development of the Valley of the Dawn. His lifelong interest in questions of spirituality and familiarity with esoteric literature suited him to the task of systematizing Aunt Neiva's visionary experiences and giving them intellectual vigor. While Sassi drew inspiration from eclectic sources, esoteric philosophies furnished key conceptual resources that helped him craft a master narrative for the Order that was universal in scope.

Sassi embedded his discussion of Aunt Neiva's experiences in a cosmology and macrohistory structured around esoteric, and more particularly, theosophical themes: the gradual descent of divine spirit into matter and back; the progression of humanity through various evolutionary stages (root races); the significance of technologically advanced 
civilizations on lost continents; the decline of the Equitumans (Lemurians) and the Tumuchy (Atlanteans); and the calamitous transition to the New Age (Third Millennium) as the universe takes its inevitable U-turn back to spirit. Equally central to the Doctrine are other ideas disseminated to the West mainly through Theosophy and its offshoots: the universal laws of karma and reincarnation; a hierarchy of cosmic Masters who have perfected themselves and now seek to assist humans; the distinction between the eternal individuality and the ephemeral personality; and a highly romanticized vision of the mystic East that permeates the Valley of the Dawn. References to the "enchanted worlds of the Himalayas," for example, regularly feature in the community's corpus of prayers and ritual formulae and members claim to work with forces from the Indian Space Current (a Corrente Indiana do Espaço) and the White Current of the Great Orient (Corrente Branca do Grande Oriente).

Sassi also saw resonances between Aunt Neiva's astral voyages and the accounts of a civilizing vanguard from Capella described by Brazilian spiritist writers Chico Xavier and Edgard Armond. As Mikael Rothstein observed, the notion that the Masters originated from remote and mysterious places "was in accordance with classical theosophical ideas, but distant planets provided a new and fresh realm for theosophical imaginations," especially as formerly remote or inaccessible regions of the world became better known to Westerners and lost some of their mystery. ${ }^{68}$

As reimagined through an esoteric lens, the spiritual intermediaries cultivated at the Valley of the Dawn, which include entities common to spiritist, Umbanda, and other Afro-Brazilian religions as well as Christian figures such as Jesus and Catholic saints, were reconceived either as the roupagens ("garments") of highly advanced Masters, or as themselves cosmic Masters. In the words of a veteran Jaguar whom I interviewed, what may appear to be familiar denizens of the Brazilian spirit world are in reality "voyagers from the stars, creatures who come from another intergalactic system" who "inhabit dimensions that we cannot even fathom." 69

The Capelinos-morally, technologically, and spiritually evolved extraterrestrials sent to Earth to aid human beings-function as the "Space Brothers," or what Christopher Partridge referred to as "descended masters," found in other theosophically influenced UFO religions of the post-World War Two era such as the Aetherius Society, UNARIUS, MarkAge, and others. ${ }^{70}$ And in a similar fashion to these groups, Aunt Neiva's prophetic voice was based in part on the claim that she was selected by these extraterrestrials, with whom she enjoyed privileged communications, to advance their mission on Earth.

I have discussed the Valley of the Dawn as a UFO religion elsewhere, ${ }^{71}$ but the movement also offers a fascinating example of the distinctive "pattern of thought" called Western esotericism, in Antoine 
Faivre's influential formulation. ${ }^{72}$ The Doctrine's emanationist cosmology, hierarchy of highly evolved intermediary beings, and concern with human spiritual evolution exemplify Faivre's four intrinsic characteristics of Western esotericism. ${ }^{73}$ These characteristics are: (a) correspondences that link the microcosm to the macrocosm, as in the septenary composition of the universe and human beings; (b) living nature, which is the comprehension of the cosmos as a complex, hierarchical being animated by a divine energy that emanates throughout all levels; (c) imagination and mediations expressed here as cosmic Masters and spiritual guides whom adherents experience via imaginative perception and ritual; and (d) the experience of transmutation, an inner transformation or change of state as present-day Jaguars engage in practices aimed at redeeming their negative karma and deepening their knowledge of the principles that govern the universe.

Considering the Valley of the Dawn as an example of Western esotericism sheds light on how a transnational set of ideas with deep historical roots has interacted with local realities in Brazil, bringing that country into a scholarly conversation that has focused almost exclusively on European and North American contexts. It enables the Valley of the Dawn to be compared with other esoteric movements, past and present, and enables the identification of continuities and cross-fertilizations as well as differences.

As Andrew Dawson put it in his survey of New Age religions in Brazil, the Doctrine's "mind-boggling abstruse cosmological system" has struck most observers as incomprehensively complex and even nonsensical. ${ }^{74}$ I myself struggled to understand the movement's obscure terms and labyrinthine theology as described by my informants in the field and in the doctrinal writings produced by Sassi and others. The scholarly work on Theosophy and Western esotericism more generally helped me see that the collaboration between the charismatic clairvoyant Aunt Neiva and her interpreter Mário Sassi created a Brazilian form of Western esotericism that transformed the local and Brazilian into something far more transcendent. Just as the humble Brazilian citizen Tiãozinho was revealed to be the Capelino Stuart, interstellar engineer, and cosmic Master, esoteric literature provided an expansive framework for Aunt Neiva's visions that spoke to its local context while anchoring it in the more universalizing vision of esotericism.

\section{ENDNOTES}

${ }^{1}$ Wouter Hanegraaff, New Age Religion and Western Culture: Esotericism in the Mirror of Secular Thought (Leiden: Brill, 1996); and Hanegraaff, Esotericism and the Academy: Rejected Knowledge in Western Culture (Cambridge: Cambridge University Press, 2012). 
${ }^{2}$ Deis Siqueira, As novas religiosidades no Ocidente: Brasília, cidade mística (Brasília: Editora UnB/FINATEC, 2003); Deis Siqueira and Ricardo Barbosa de Lima, eds., Sociologia das adesões: Novas religiosidades e a busca místico-esotérica na capital do Brasil (Rio de Janeiro: Garamond, 2003), 144.

${ }^{3}$ Robert Carpenter, "The Mainstreaming of Alternative Spirituality in Brazil," in New Religious Movements in the Twenty-First Century: Legal, Political and Social Challenges in Global Perspective, eds. Phillip Charles Lucas and Thomas Robbins (New York: Routledge, 2004), 220.

${ }^{4}$ The roots of OSOEC go back to an earlier organization called the União Espiritualista Seta Branca (Spiritualist Union Seta Branca), or UESB, founded in 1959 by Aunt Neiva and a medium known as Mother Neném. In 1964 the two women parted ways and Aunt Neiva relocated, along with a small number of family members and followers, to Taguatinga, a satellite town on Brasília's periphery. In 1969 the group moved to its present location at the Vale do Amanhecer. Administratively, the Vale do Amanhecer is part of the municipality of Planaltina in the federal district.

${ }^{5}$ In this, the Valley can be considered part of a history of religious movements founded by charismatic women who "relied on a male partner to institutionalize their movements," as Catherine Wessinger, Dell DeChant, and William Michael Ashcraft put it. See their entry on "Theosophy, New Thought, and the New Age Movements," in The Encyclopedia of Women and Religion in North America, eds. Rosemary Skinner Keller and Rosemary Radford Ruether (Bloomington: Indiana University Press, 2006), 753.

${ }^{6}$ I conducted fieldwork at the Valley of the Dawn's Mother Temple outside Brasília for a total of 9 months in 2012, 2015, and 2017.

${ }^{7}$ Ana Lúcia Galinkin, A Cura no Vale do Amanhecer (Brasília: TechnoPolitik, 2008), 59.

${ }^{8}$ I am aware of three publications that discuss Mário Sassi's biography and contributions to the Valley at greater length than the paragraph or so that typically he is allotted. In all cases, the authors visited the Mother Temple and were received by Sassi. In addition to serving as their guide, Sassi seems to have spent some time explaining the movement's beliefs and practices in some depth and discussing his own biography. The first is a three-part series written by Father José Vicente César for a magazine aimed at Catholic clergy: "O Vale do Amanhecer: Parte I," in Atualização: Revista de Divulgação Teológica Para o Cristão de Hoje 95/96 (Belo Horizonte: Editora o Lutador, 1977); and "O Vale do Amanhecer: Partes II e III” in Atualização: Revista de Divulgação Teológica Para o Cristão de Hoje 97/98 (Belo Horizonte: Editora o Lutador, 1978). The second is Ana Lúcia Galinkin's master's thesis from 1977, which was published in 2008 as $A$ Cura no Vale do Amanhecer (Brasília: TechnoPolitik, 2008). The third is an academic article written by two social psychologists based on a visit to the Valley in 1984: Aracky Martins Rodrigues and Francine Muel-Dreyfus, "Reencarnações: Notas de Pesquisa sobre uma Seita Espírita de Brasília," in Aracky Martins Rodrigues, Indivíduo, Grupo e Sociedade: Estudos de Psicologia Social, 233-260 [São Paulo: Editora USP, 2005 (1987)]. The first and third publications in particular seem to be the main sources for biographical information about Sassi repeated in subsequent works about the Valley written by scholars and Valley members. Drawing on these accounts as well as research derived from 


\section{Nova Religio}

his own experience as a Valley member, historian Marcelo Reis concluded that both Mário Sassi and Aunt Neiva were necessary to the establishment of the Order. Without Sassi "and his intense participation in the construction of the Valley of the Dawn," he wrote, "the realization of Aunt Neiva's mission would not have been the same." Reis devotes several paragraphs to Sassi in "Tia Neiva: Traços de um Itinerário Existencial," in Deis Siqueira, Marcelo Reis, Jairo Zelaya Leite, and Rodrigo M. Ramasotte, Vale do Amanhecer: Inventário Nacional de Referências Culturais (Brasília: Superintendência do IPHAN no Distrito Federal, 2010), 195-196. Likewise, Reis's own Ph.D. dissertation, which focused mostly on Aunt Neiva, also included attention to Sassi's contributions. See Reis, "Tia Neiva: A Trajetória de Uma Líder Religiosa e Sua Obra, O Vale do Amanhecer (1925-2008)," Ph.D. diss., University of Brasília, 2008. Members of the Valley also have produced their own biographical literature on Aunt Neiva, among them are Bálsamo Álvares Brasil de Lucena, ed. Neiva Chaves Zelaya (Tia Neiva): Autobiografia Missionária (Brasília: Vale do Amanhecer, 1992) and Carmem Lúcia Zelaya, Neiva: Sua Vida pelos Meus Olhos (Brasília: Coronário, 2014). The latter is an account of Aunt Neiva's early life written by her eldest daughter. Mário Sassi wrote about Aunt Neiva's life and experiences in some detail in Sob os Olhos da Clarividente (Brasília: Vale do Amanhecer, n/d); 2000: A Conjunção de Dois Planos (Brasília: Vale do Amanhecer, 1974) and Minha Vida, Meus Amores: Autobiografia de Tia Neiva (Brasília: Vale do Amanhecer, 1985).

9 This is true even of my earlier work on the Valley (Kelly E. Hayes, "Intergalactic Space-Time Travelers: Envisioning Globalization in Brazil's Valley of the Dawn," Nova Religio 16, 4 (May 2013): 63-92).

${ }^{10}$ Disobsession is a spiritual therapy associated with Kardecist Spiritism that is aimed at freeing individuals from the perturbing influence of inferior spirits, called obsessors (obsessores).

11 Massimo Intorvigne, "The Vale do Amanhecer: Healing and spiritualism in a globalized Brazilian new religious movement," Sociologia, Revista da Faculdade de Letras da Universidade do Porto, 26 (2013): 189.

12 The quote is from James Holston, "Alternative Modernities: Statecraft and Religious Imagination in the Valley of the Dawn," American Ethnologist 26, no. 3 (1999): 607. But the basic idea has been articulated by many other scholars, among them: Marcelo Camurça, "Espaços de Hibridização, Dessubstancialização da Identidade Religiosa e Idéias Fora do Lugar," Ciencias Sociales y Religión/Ciências Sociais e Religião 5, 5 (Oct 2003): 37-65; José Jorge de Carvalho, "Um Espaço Público Encantado: Pluralidade Religiosa e Modernidade no Brasil," Série Antropologia 249 (Universidade de Brasília, 1999): 1-22; Carmen Luisa Chaves Cavalcante, Dialogias no Vale do Amanhecer: Os Signos de um Imaginário Religioso (Fortaleza: Expressão Gráfica Editora, 2011); Amurabi Pereira Oliveira, "Imaginário e construção da realidade: um olhar sobre as visualidades do Vale do Amanhecer," Cultura Visual, 13 (May 2010): 71-83; Deis Siqueira, "Unconventional Religiosities and the New Age in Vale do Amanhecer (Valley of the Dawn), Brasilia," in New Age in Latin America: Popular Variations and Ethnic Appropriations, eds. Angela Renée de la Torre Castellanos, María Cristina del Refugio Gutiérrez and Nahayeilli Juárez-Huet, 243-264 (Leiden: Brill, 2016).

13 As he was quoted by Father José Vicente César, a Catholic priest who studied the Valley for an extended period beginning in 1976 and wrote about it in three 
parts for a theological publication. See César, "O Vale do Amanhecer: Parte I," in Atualização: Revista de Divulgação Teológica Para o Cristão de Hoje 95/96 (Belo Horizonte: Editora o Lutador, 1977) and César, "O Vale do Amanhecer: Partes II e III" in Atualização: Revista de Divulgação Teológica Para o Cristão de Hoje 97/98 (Belo Horizonte: Editora o Lutador, 1978). At some point in time, César's articles were combined into one document by Valley members, which is what I consulted. This document circulates widely as part of the Valley's archive. Although it appears to contain all of the material of the original articles, including the original citation information, the document lacks page numbers.

${ }^{14}$ Sassi's daughter Cací told me that the unnamed person was actually her mother, Moema, who sought Aunt Neiva's assistance with her troubled marriage to Sassi. Although Sassi was averse to the idea of visiting a clairvoyant for marital advice, Moema had insisted-much to her later regret. In his various descriptions of his introduction to Neiva, Sassi described his initial reluctance but never mentioned his first wife. Interview with Cací Sassi, Brasília, July 2017.

${ }^{15}$ Mário Sassi, 2000: A Conjunção de Dois Planos (Brasília: Vale do Amahecer, 1974), 15.

${ }^{16}$ Interview with Mário Sassi by Mestre Gilmar, November 1994, https:// youtu.be/SkPevoc6Np0, accessed 14 April 2018.

17 Sassi, Conjunção, 19; 23. The reference to the "Spirit of Truth" alludes to a passage in the biblical Gospel of John where Jesus promises his disciples that God will send them an advocate in the form of the Spirit of Truth to comfort and be with them. Although the world will not recognize this advocate, Jesus's disciples will know him for he "abides with you and will be in you." Jn. 14:16-17 NRSV. Edgard Armond's book Os Exilados de Capela cites other spirit entities, among them Chico Xavier's spirit mentor Emmanuel, as numbering among the many Spirits of Truth who have guided humanity's spiritual evolution. Edgard Armond, Os Exilados da Capela: Esboço Sintético da Evolução Espiritual no Mundo [São Paulo: Editora Aliança, 1987 (1949)].

18 Sassi, Conjunção, 19.

19 Ana Lúcia Galinkin estimated 9,000 adepts in 1975 (Galinkin, A Cura, 19). A study in 1979 cited by Aracky Martins Rodrigues and Francine Muel-Dreyfus gave a figure of 40,000 (Rodrigues and Muel-Dreyfus, "Reencarnações," 236).

${ }^{20}$ A sample of Sassi's published works include: Sob Os Olhos da Clarividente (Brasília: Vale do Amanhecer, n/d); No Limiar do Terceiro Milênio (Brasília: Vale do Amanhecer, 1974); 2000: A Conjunção de Dois Planos (Brasília: Vale do Amanhecer, 1974); Instruções Práticas para os Médiuns, 7 volumes (Brasília: Vale do Amanhecer, 1977); O Que éO Vale do Amanhecer (Brasília: Vale do Amanhecer, 1979); Partida Evangélica: Apostila para Distribuição entre os Médiuns (Brasília: Vale do Amanhecer, 1985); Neiva Chaves Zelaya, Minha Vida, Meus Amores: Autobiografia de Tia Neiva, ed. Mário Sassi (Brasília: Vale do Amanhecer, 1985).

${ }^{21}$ In a pattern common among other religions established in the nineteenth and twentieth centuries, Sassi used science as a rhetorical tool and a way to legitimate claims about the nature of reality that are not empirically verifiable. Likewise, contemporary Valley members insist that their beliefs and practices are thoroughly rational and scientifically proven. As Benjamin Zeller observed, thanks to the authority given to science in the modern world, being "scientific" 


\section{Nova Religio}

is often central to the self-understanding of adherents of new religious movements. However, "their understandings of science are fluid, changing, and seldom follow rigorous academic definitions of the term." Benjamin Zeller, "At the Nexus of Science and Religion: UFO Religions," Religion Compass 5, 11 (2011): 667.

${ }^{22}$ João Batista Brito Pinto, "Breve Histórico da Teosofia no Brasil: Desde os Seus Primórdios Até a Fundação da Seção Nacional da Sociedade Teosófica, em 1919," in Boletim do CIBLA (Círculo Blavatsky) (Porto Alegre, Rio Grande do Sul: June 1993), 19-22.

23 According to Pinto, the first was Leadbeater's The Other Side of Death in 1905 (Pinto, "Breve Histórico," 19).

${ }^{24}$ Galinkin, A Cura, 57.

25 Interview with Cací Sassi, Brasília, 26 July 2017.

${ }^{26}$ Interview with Iraê Sassi, Brasília, 20 July 2017.

27 Interview with Lêda Franco de Oliveira, Sobradinho (Brazil), 29 July 2017. The movement that Sassi founded continues to this day under Lêda's direction as the Tumuchy Temple of Spiritualist Christian Order of the Universal Light (Templo Tumuchy da Ordem Espírita Cristã da Luz Universal).

${ }^{28}$ In my 2013 article (Hayes, "Intergalactic Space-Time Travelers"), I erroneously gave the date of Sassi's death as 1995, following other printed sources (principally Siqueira et al., Vale do Amanhecer: Inventário). However, both Sassi's daughter Cací and his third wife Lêda confirmed to me that he actually died in December of 1994.

${ }^{29}$ See Reis, "Tia Neiva: Traços de um Itinerário Existencial," 194-200. On Sassi’s departure from the Valley, see Erich Gomes Marques, "Os Poderes do Estado no Vale do Amanhecer: Percursos Religiosos, Práticas Espirituais e Cura," M.A. thesis, University of Brasília, 2009, 8-9. Sassi himself wrote several letters detailing his perspective on the schism, which he attributed to the other high-ranking members' refusal to sanction his work with the spirit of Aunt Neiva, whom Sassi claimed was being incorporated by a medium. Three of these letters written in 1990 are available under the heading "A Cisão" (the Schism) at http:// www.valedoamanhecer.net.br/publique /news_content.php?fileName=271, accessed 18 August 2012.

${ }^{30}$ Garry Trompf defined esoteric macrohistory as "a discernible manner of thinking about the past as an unfolding descent of all Creation from the Divine, eventuating in the materialization of humanity, and culminating in the re-ascent of purified souls back up to their true Home." Trompf, "Theosophical Macrohistory," in Handbook of the Theosophical Current, eds. Olav Hammer and Mikael Rothstein, 375-403 (Leiden: Brill, 2013), 375-376.

31 Trompf, "Theosophical Macrohistory," 376.

32 Umahã is sometimes spelled Umahan or Humarran.

33 Bálsamo Álvares do Brasil de Lucena, ed. Tia Neiva: Autobiografia Missionária (Planaltina: Obras Sociais da Ordem Espiritualista Cristã, 1992), 12 (selfpublished book).

${ }^{34}$ Neiva Chaves Zelaya, Minhas Vidas, Meus Amores, Autobiografia de Tia Neiva, ed. Mário Sassi (Planaltina: Obras Sociais da Ordem Espiritualista Cristã, 1985), 
preface (self-published book, no page numbers). This is the only reference that I have encountered to Kuthumi in Sassi's published works.

35 Francisco (Chico) Xavier (1910-2002) was a well-known Brazilian spirit medium who psychographed dozens of spiritist books. Edgard Armond (1894-1982) was a leader of the spiritist movement in São Paulo and was involved in the codification and systematization of spiritist doctrine and spiritist organizations in Brazil more generally.

${ }^{36}$ A reference to the star Capella, also known as Alpha Aurigae, visible from Earth as the brightest star in the constellation of Auriga. It is referred to almost exclusively as a planet in Valley doctrine.

37 Sassi, Conjunção, 32.

38 Sassi, Conjunção, 31. That the Capellans are described as physical beings makes them closer to Blavatsky's original concept of the Masters than the socalled "Ascended Masters" that developed among other theosophically oriented UFO groups, as Benjamin Zeller pointed out to me (personal communication May 2019).

39 Sassi, Conjunção, 79.

${ }^{40}$ Sassi, Conjunção, 61. According to Mikael Rothstein, the founder of the Aetherius Society, George King similarly claimed that extraterrestrial Space Brothers could not interact directly with uninitiated humans for "karmic reasons." See Rothstein, "Mahatmas in Space: The Ufological Turn and Mythological Materiality of Post-World War II Theosophy," in Handbook of the Theosophical Current, eds. Olav Hammer and Mikael Rothstein (Leiden: Brill, 2013), 227.

${ }^{41}$ Sassi, Sob os Olhos da Clarividente (Brasília: Vale do Amanhecer, n/d), 131.

${ }^{42}$ Sassi, Conjunção, 167-178.

43 In essence, root races demarcate major stages within a vast, cyclical progression through which cosmic consciousness descends into matter and, reversing course, ascends again. James Santucci described root races as the "various stages experienced by the reincarnating soul or 'monad' [i.e., human entity] along an incredibly lengthy series of cyclical progressions ... before reaching the stage of a 'perfect, septenary being,' in which consciousness is fully integrated in its operation of the 'vehicles' or 'bodies' corresponding to the seven planes of existence." Each of the seven root races (and their associated subraces) is characterized by differing admixtures of consciousness (or spirit) and matter. See Santucci, "The Notion of Race in Theosophy, Nova Religio 11, 3 (2008): 38.

${ }^{44}$ Sassi, Conjunção, 173.

45 Sassi, Conjunção, 173.

${ }^{46}$ Sassi, Conjunção, 174. Later in the book, Sassi narrated these events somewhat differently, describing the Tumuchy as "wise" Equitumans who had returned to Capella and there received new instructions from the Masters before being reincarnated on Earth in bodies that were more suited to both the terrestrial environment and their task (219).

${ }_{47}^{4}$ Sassi, Conjunção, 190. 


\section{Nova Religio}

49 José Carlos Nascimento Silva, ed. O Que é o Vale do Amanhecer: Uma pequena sintese da história, atividades e localização, no tempo e no espaço, do movimento doutrinário da Ordem Espiritualista Cristã, em Brasília, no Vale do Amanhecer (based on work edited by Mário Sassi in 1979) (Planaltina: Vale do Amanhecer, 2004), 19. 50 Sassi, Conjunção, 226.

${ }^{51}$ Psychographed works are those written through the spiritist technique of automatic writing, wherein a spirit agency is believed to produce writing through the medium's own hand while the latter is in a state of mediumistic trance.

${ }^{52}$ Francisco Cândido Xavier, A Caminho da Luz: História da Civilização à Luz do Espiritismo, ditada pelo espírito Emmanuel (São Paulo: Editora FEB [Federação Espírita Brasileira], 1939); Edgard Armond, Os Exilados da Capela: Esboço Sintético da Evolução Espiritual no Mundo [São Paulo: Editora Aliança, 1987 (1949)]. The idea that a group of advanced extraterrestrial beings migrated to Earth from another sphere and influenced the development of the "Adamic race" also was discussed in Allan Kardec's La Genèse, les Miracles et les Preditions selon le Spiritisme (Paris: Union Spirite Française et Francophone, 1868).

53 Only Armond explicitly used the term root race in his account. Xavier, like Sassi, does not mention it.

54 Allan Kardec, Genesis: The Miracles and the Predictions According to Spiritism [New York: Spiritist Alliance for Books, 2003 (1868) ], 124-125. Kardec goes on to say that this group was "exiled on the already peopled Earth, but peopled by primitive men yet in ignorance, to whom their mission was to effect their progress by carrying among them the light of a developed intelligence... Their intellectual superiority proves that the world from which they came was more advanced than this Earth; but that world entering upon a new phase of progress, these spirits, by their obstinacy not placing themselves at the required heights, would have been a hindrance to the providential march of events. This is why they were expelled" (127). Charles W. Leadbeater also wrote that human evolution on Earth was accelerated by the "Lords of the Flame," highly advanced beings from Venus who were transferred to the Earth in order to assist in the delicate transition between root races. These extraterrestrial beings "have produced a wonderful effect upon our evolution. The intellect of which we are so proud is almost entirely due to Their presence." He goes on to stay that while most stayed only through that critical period, a few continue to help humans as members of the Great White Brotherhood, the collective of enlightened Masters who guide the spiritual development of the human race. See Charles W. Leadbeater, A Textbook of Theosophy (Adyar, India: The Theosophist, 1912), 132, available at https:// www.theosophical.ca, accessed 6 May 2018.

55 Sassi, Conjunção, 80.

56 Sassi, Conjunção, 80.

57 Sassi, Conjunção, 149.

58 Armond, Exilados, 10.

59 Sassi, Conjunção, 225.

${ }^{60}$ Sassi explained the Capelinos' presence on Earth sometimes in contradictory ways, at one point describing a conversation in which a Capelino named Amanto tells Aunt Neiva that he and his brethren "can't leave their spaceships because we would be crushed by the density of planet Earth," although in ancient times 
"we could still establish bases on the [Earth's] surface, where we could leave the ships with relative safety. But this was an abnormality that required enormous expenditure of precious energies, and it was only done according to the plans of the time." See Sassi, Conjunção, 207.

${ }^{61}$ Sassi, Conjunção, 82.

${ }^{62}$ For more on this, see Kelly E. Hayes, "Spirits of the Space Age: The Valley of the Dawn as a UFO Religion," in Handbook of UFO Religions, ed. Benjamin E. Zeller (Leiden: Brill, in press).

${ }^{63}$ Sassi, Conjunção, 113.

${ }^{64}$ Pierini, "Journey," 203.

65 Entry on "Jesus" in Souza, Dicionário, n/p.

${ }^{66}$ Cavalcante, Dialogias, 80.

${ }^{67}$ Robert Ellwood and Catherine Wessinger, "The Feminism of 'Universal Brotherhood': Women in the Theosophical Movement," in Women's Leadership in Marginal Religions: Explorations Outside the Mainstream, ed. Catherine Wessinger (Urbana, Illinois: University of Illinois Press), 70-71.

${ }^{68}$ Mikael Rothstein, "Mahatmas in Space: The Ufological Turn and Mythological Materiality of Post-World War II Theosophy," in Handbook of the Theosophical Current, ed. Olav Hammer and Mikael Rothstein (Leiden: Brill, 2013), 218-219.

${ }^{69}$ Interview with Joaquim Vilela, Vale do Amanhecer, 8 July 2015. This quote also appeared in Kelly E. Hayes, "I Am a Psychic Antenna: The Art of Joaquim Vilela," Black Mirror, in press.

${ }^{70}$ See Christopher Partridge's discussion of ascended and descended masters in The Re-Enchantment of the West, Vol. 2: Alternative Spiritualities, Sacralization, Popular Culture and Occulture (New York: T \& T Clark International, 2005), 206.

71 Hayes, "Spirits of the Space Age."

72 Kocku Von Stuckrad, Western Esotericism: A Brief History of Secret Knowledge, trans. Nicholas Goodricke-Clarke (London: Routledge, 2014 [2005]), 3.

73 Antoine Faivre, Access to Western Esotericism (Albany: State University of New York Press, 1994), 10-15.

74 Andrew Dawson, New Era - New Religions: Religious Transformation in Contemporary Brazil [New York: Routledge 2016 (2007)], 50. 